\title{
New enigmatic Andean bee species of Protandrena (Hymenoptera, Andrenidae, Panurginae)
}

\author{
Victor H. Gonzalez ${ }^{1} \&$ Luisa Ruz ${ }^{2}$
}

${ }^{1}$ Department of Ecology and Evolutionary Biology, Haworth Hall, 1200 Sunnyside Avenue, University of Kansas, Lawrence, Kansas 660457523, USA. vhgonza@ku.edu (Corresponding author).

${ }^{2}$ Laboratorio de Zoología, Pontificia Universidad Católica de Valparaíso, Av. Brasil 2950, Valparaíso, Chile. 1ruz@ucv.cl

\begin{abstract}
New enigmatic Andean bee species of Protandrena (Hymenoptera, Andrenidae, Panurginae). Panurgine bees are diverse and abundant in temperate areas of the Americas but poorly represented to nearly absent in the tropics. We describe and illustrate five distinctive new species of the genus Protandrena that occur at high altitudes (2000-3400 $\mathrm{m}$ ) in the Andes, from Venezuela to Ecuador. The species are also described to make the names available in forthcoming papers on their biology. These Andean species resemble some members of the subgenus Heterosarus but differ from it, as well as from any other subgenera of Protandrena, primarily in characters of the male genitalia and hidden sterna. The South American Protandrena s. 1. are morphologically highly diverse and a complete study of the group is needed before supraspecific names are proposed for unusual species. Thus, to avoid further nomenclatural changes, we decided not to place these species in a new subgenus or any of the available subgenera. We also provide notes on the biology for some of the species.
\end{abstract}

KEYWORDS. Apoidea; Colombia; floral records; South America; taxonomy.

RESUMO. Novas espécies de abelhas andinas do gênero Protandrena (Hymenoptera, Andrenidae, Panurginae). As espécies de abelhas da subfamília Panurginae nas áreas temperadas das Américas são diversas e abundantes, mas pouco representadas ou até ausentes nos trópicos. São descritas e ilustradas cinco novas espécies do gênero Protandrena que ocorrem em grandes altitudes (2000-3400 m) nos Andes, da Venezuela ao Equador. As espécies são descritas para que se tenham nomes válidos em artigos sobre sua biologia. Estas espécies andinas são semelhantes a alguns membros do subgênero Heterosarus, mas diferem dele, assim como do subgênero Protandrena, primariamente pelos caracteres da genitália do macho e pelos esternos ocultos. Protandrena s. 1. sulamericanos são morfologicamente muito diversos e um estudo completo do grupo deverá ser feito antes de serem propostos nomes supra-específicos para essas espécies. Portanto, para evitar futuras mudanças na nomenclatura, foi decidido não alocar essas espécies em um novo subgênero ou em qualquer outro. São fornecidas também notas da biologia para algumas espécies.

PALAVRAS-CHAVE. América do Sul; Apoidea; Colombia; recursos florais; taxonomia.

The purposes of this work are to describe and illustrate five distinctive new species of the bee genus Protandrena Cockerell from the higher tropical Andes (2000-3400 m), and to make their names available in forthcomings papers on their biology. Panurgine bees are diverse and abundant in temperate areas of the Americas but poorly represented to nearly absent in the tropics (Michener 2000). As far as we know, only a few species in the genera Acamptopoeum Cockerell and Protandrena occur in the northwestern part of South America, from Venezuela to Ecuador (Gonzalez 2004; Gonzalez \& Engel 2004). The Protandrena species described in this work, as well as at least three other presumably related species from the Peruvian and Bolivian Andes, have the following characteristics in common: body predominantly dark brown to black, two submarginal cells (Fig. 1), propodeal triangle basally glabrous, and mesoscutum finely punctured. The sixth sternum of the male has a V-shaped midapical emargination (Figs. 13-16), and the tibial scopa of the female is sparsely covered with simple or minutely branched hairs. Thus, in the key to the subgenera of Protandrena of Michener (2000), these species run out to the subgenus Heterosarus Robertson. However, they differ from Heterosarus and any other known subgenera of Protandrena primarily in male characters of the hidden sterna and genitalia. The apical lobes of the seventh sternum are narrow and distally retrorse (Figs. 17-20) as in Protandrena s. str. and Metapsaenythia Timberlake, but the apex of these lobes lack the distinctive spatulate hairs present in the latter. In addition, Metapsaenythia has a hairy propodeal triangle and a metasoma frequently red. The gonostylus and gonocoxite are hairless and completely fused (Figs. 25-32). Such structures have long branched hairs and can be distinguished, at least ventrally, in the subgenera Heterosarus and Metapsaenythia.

Given these peculiarities, our first impression was to place these Andean species into a new subgenus. However, the South American Protandrena s. 1. are morphologically highly diverse, and many species cannot easily assigned to any of the known subgenera (e.g., Ruz 1986; Ruz \& Chiappa 2004; Ramos \& Melo 2006). A complete revision of the group is needed before supraspecific names are proposed for unusual species. Therefore, to avoid further nomenclatural changes, we decided not to place these Andean species in a new subgenus or in any of the available subgenera. We also provide notes on the biology for some of the species. 


\section{MATERIALAND METHODS}

The morphological description and illustrations were made using an Olympus SZ60 stereomicroscope. Morphological terminology follows that of Michener (2000) and, in general, Harris (1979) for surface sculpturing. Description format follows that of Gonzalez (2004). The abbreviations F, S, T, OD, and PD are used for antennal flagellomere, metasomal sternum and tergum, and ocellar diameter and puncture diameter, respectively. Type specimens are deposited in the following institutions: Instituto de Ciencias Naturales (ICN), Universidad Nacional de Colombia (Bogotá), and Entomology Division, Natural History Museum, University of Kansas (SEMC), Lawrence, KS, USA.

\section{Protandrena bachue sp. nov.}

Diagnosis. Males can be recognized by the following combination of characters: clypeus with an inverted T-shaped yellow maculation (Figs. 1, 2), antennal flagellum strongly crenulate (Fig. 5), and S5 with midapical margin bearing a long row of spines (Fig. 9). Females can be distinguished by the combination of facial fovea about $2.4 x$ longer than broad (Fig. 33 ) and antennal flagellum weakly crenulate, especially the basal segments (Fig. 35).

Holotype. Male. Body length 7.9-11.8 mm; forewing length 7.0-7.1 mm; head width 2.4-2.5 mm. Structure. Head 1.3x wider than long; inner orbits subparallel (Figs. 1, 2); interalveolar distance $2 \mathrm{OD}, 0.8 \mathrm{x}$ length of the alveolorbital distance; alveolus diameter equal to $\mathrm{OD}$; ocellocular distance $3.3 \mathrm{OD}, 2.1 \mathrm{x}$ greater than ocelloccipital distance; interocellar distance 1.4 OD; compound eye $2.3 \mathrm{x}$ longer than wide; clypeus $2.5 \mathrm{x}$ broader than long, projecting about 0.8 of eye width in lateral view; gena as broad as eye in profile; supraclypeal area, between antennae, distinctly protuberant; frontal line elevated just above antennal sockets to half distance between antennal sockets and median ocellus, ending at that point; anterior tentorial pit on outer subantennal suture, close to the intersection with the epistomal suture; length of inner subantennal suture about three fourths of the outer; facial fovea $2.9 x$ longer than broad, about half of scape length; scape $2.5 x$ longer than broad, antennal flagellum subequal to head width, strongly crenulate (Fig. 5); F1 1.5x longer than F2 and F3 individually, remainder segments about as long as broad, except F11 longer than broad. Stigma 4x longer than wide; prestigma $2 \mathrm{x}$ longer than broad. Mesosoma about as wide as head width; mesoscutum wider than long, $2.5 \mathrm{x}$ longer than mesoscutellum, $4.4 \mathrm{x}$ longer than metanotum; propodeum with basal part almost horizontal, about three fourths of mesoscutellum length; fore basitarsus longer and slender than mid basitarsus; mid tibial spur curved, with coarse teeth, less than half of mid basitarsus length; basitibial plate well defined, margins carinate; hind tibia with upper marginal carina weakly toothed near to basitibial plate; hind tibial spurs slightly curved, inner spur longer than the outer. Claws cleft, inner ramus shorter than the outer. Lateral fovea of $\mathrm{T} 2$ ellipsoid, $1.7 \mathrm{x}$ longer than broad; S5-S8, and genital capsule as in Figs. 9, 13, $17,21,25,29$. Coloration. Black, except for the yellow pronotal lip and clypeus with a yellow maculation as in Figs. 1, 2; apex of mandible and tarsi of all legs yellowish to reddish brown. Wings brownish, veins and stigma dark brown. Pubescence. Head, mesoscutum, mesoscutellum, and propodeum with predominantly black erect hairs; scape with long hairs, $2 \mathrm{x}$ as long as maximum scape diameter. Mesoscutellum with hairs longer than those on disc of mesoscutum; ventral area of mesepisternum, coxae, trochanters, and sterna with grayish hairs; inner surface of legs predominantly with brownish hairs, outer surface with blackish hairs. Metasomal terga mostly bare, only with short (1 OD), semierect, sparse ferruginous hairs; T6 with long (2 OD), semierect, blackish hairs; T7 with hairs denser than on T6, except for a bare longitudinal median area. Sterna with sparse, short (1 OD), semierect hairs, denser, and longer on the sides of each sternum. Punctation. Labrum with basal area smooth, shining, impunctate; clypeus weakly punctured (1-2 PD), integument between punctures imbricate; supraclypeal area and lower half of face as on clypeus, except integument between punctures granular (as on the rest of face); upper half of face and vertex closely punctate, punctures strong, contiguous, and smaller than on clypeus; gena granular with faint punctures. Mesoscutum, mesoscutellum, and metanotum minutely and closely punctured $(\leq \mathrm{PD})$, integument granular between punctures; preepisternum and mesepisternum imbricate with faint punctures; metepisternum transversely striate near wing base, otherwise imbricate. Propodeal triangle with fine and weak striae; imbricate to microareolate posteriorly. Metasomal terga and sterna shiny, imbricate with minute punctures; punctation coarser and deeper on $\mathrm{T} 7$.

Female. As described for the male, except for usual secondary sexual characteristics: Structure. Head 1.1x wider than long; inner orbits diverging below (Fig. 33); ocellocular distance 3.6 OD, 1.6x greater than ocelloccipital distance; interocellar distance $1.3 \mathrm{OD}$; compound eye $2.1 \mathrm{x}$ longer than wide; gena slightly narrower than eye in profile; inner subantennal suture about three fifths as long as the outer; facial fovea $2.4 x$ longer than broad, $0.7 x$ scape length; antennal flagellum shorter than head width, slightly crenulate, especially the basal segments (Fig. 35); F1 1.8x longer than F2 and F3 individually; prestigma $2.5 \mathrm{x}$ longer than wide. Mesoscutum $4.7 \mathrm{x}$ longer than metanotum; mid tibial spur $0.8 \mathrm{x}$ mid basitarsus length, straight, with eight teeth (not including apex) as in Fig. 39; hind tibial spurs subequal in length; basitarsus with posterodistal apex strongly projected. Tibial scopa sparsely covered with long (> 4 OD) simple hairs. Fovea of T2 1.2x longer than broad; S5 with apical margin slightly concave (Fig. 37), S6 as in Fig. 41. Coloration. As in the male but without the yellow maculation on the clypeus. Pubescence. Similar to that of the male but denser on metasomal terga, darker on sterna. Punctation. Metasomal sterna with denser punctures than in the male. 


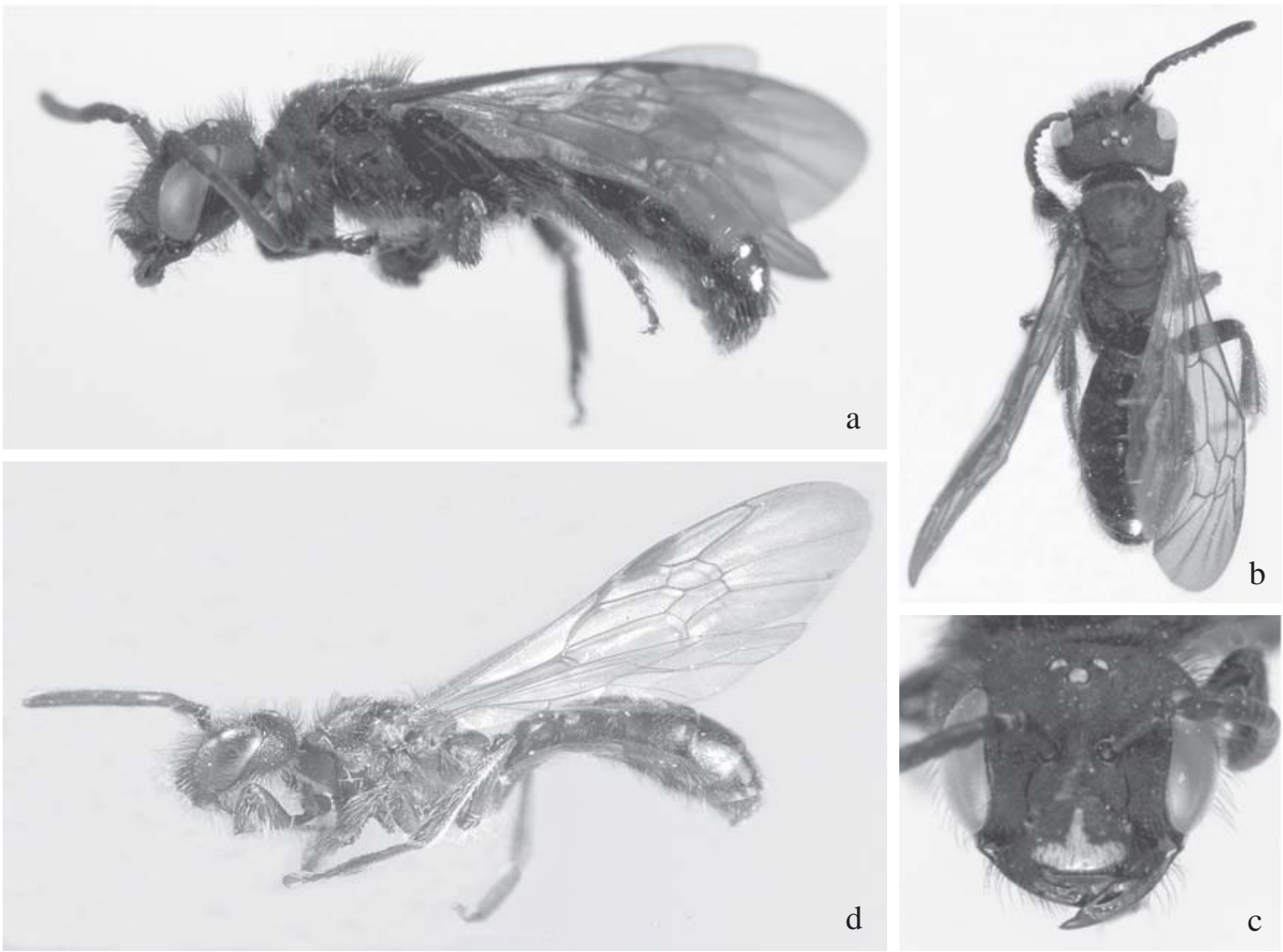

Fig. 1. Protandrena from the Andes of Colombia (Males). a-c, Protandrena bachue sp. nov. in lateral, dorsal, and frontal views (upper left and right, and bottom right, respectively); d, P. guarnensis sp. nov. in lateral view (bottom left).

Holotype: $0^{\rtimes}$, COLOMBIA, Boyacá: Santuario de Fauna y Flora de Iguaque, Lagunillas $5^{\circ} 25^{\prime} \mathrm{N}, 73^{\circ} 27^{\prime} \mathrm{W}, 3380 \mathrm{~m}$, Malaise, III-28 to IV-16 2001, P. Reina (ICN). Paratypes: $20^{\star}$, 1 i from the same locality as the holotype but on the following dates and collectors: Quebrada Carrizal, 2830 m, I-12 1990, I-6 1991, C. Sarmiento; I-4 1992, F. Rodriguez (ICN, SEMC).

Etymology. The specific name refers to the Muisca goddess Bachué. The Muisca was a South American nation that lived mainly in modern-day Cundinamarca and Boyacá highlands of Colombia. According to the legend, Bachué came out from the lake of Iguaque with a boy in her arms, giving origin to the human race. The Lake of Iguaque is located in the Iguaque Sanctuary, the type locality of this species.

Floral records. The pollen from the scopae of a single female specimen collected on December 2001 in Chingaza Natural Park (Cundinamarca, 4 30 N, 73 40’ N, 3150 m) was removed and kindly examined by $\mathrm{G}$. Bogotá. Most of the pollen grains ( $90 \%$ ) belonged to Gaultheria sp. (Ericaceae), a common genus of shrubs with showy red or white flowers. The remaining pollen types were, in order of abundance, as follows: Vallea stipularis L.F. (Elaeocarpaceae), LoutergiaPlagiocheilus (Asteraceae, tubiflorae group), and Oxalis sp (Oxalidaceae). Given the relatively low abundance of these pollen grains in the sample, they may be contaminants or were gathered accidentally during nectar visits.

\section{Protandrena maximina sp. nov.}

Diagnosis. Females of this species are similar to $P$. rangeli sp. nov. in the unmodified antennal flagellum (as in Fig. 36) and the shape of S6 (Fig. 42). However, P. maximina sp. nov. has a longer facial fovea ( $0.7 \mathrm{x}$ vs. half of scape length) and is much larger than $P$. rangeli sp. nov. (head width, 1.9-2.1 vs. $1.6-1.7 \mathrm{~mm})$.

Holotype. Female. As described for P. bachue sp nov. except for: Body length, $7.8 \mathrm{~mm}$; forewing length $5.8 \mathrm{~mm}$; head width $2.0 \mathrm{~mm}$. Structure. Head 1.2x wider than long; inner orbits subparallel; ocellocular distance $3.3 \mathrm{OD}, 2.1 \mathrm{x}$ greater than ocelloccipital distance; interocellar distance 1.4 OD; compound eye $2.2 x$ longer than wide; gena slightly narrower than eye in profile; facial fovea 3.6x longer than broad, $0.7 x$ of scape length; antennal flagellum shorter than head width, unmodified (as in Fig. 36); F1 about 2x longer than F2 and F3 individually. Stigma $3.5 \mathrm{x}$ longer than wide; prestigma $3.3 \mathrm{x}$ longer than wide. Mesoscutum 5.4x longer than metanotum; mid tibial spur $0.8 \mathrm{x}$ mid basitarsus length, straight, with eleven teeth (seven in three paratypes). S5 with apical margin nearly straight (as in Fig. 38), S6 as in Fig. 42. Fovea of T2 2x longer than broad.

Holotype: ㅇ, VENEZUELA, Mérida: 42.4 km NW Mérida, near La Carbonera, 8`37’38’'N, 74²1'10”'W, 2360 m, V-25 1998, 

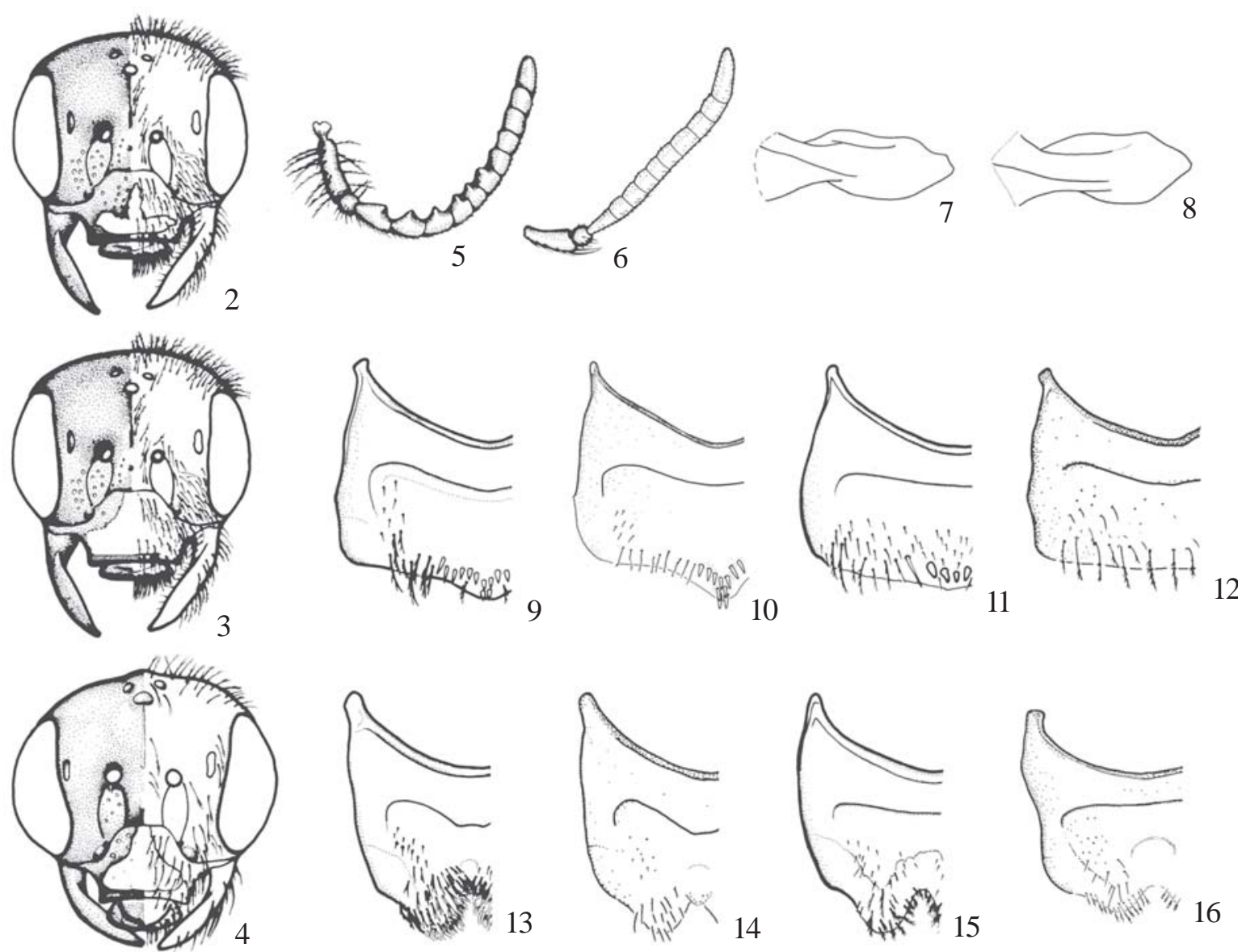

Figs. 2-16. Males of Protandrena. 2-4, face showing integumental color (left half) and pubescence (right half), stippling indicates black, remainder yellow; 5, 6, crenulate and normal antennal flagella; 7, 8, outer view of mandibles; 9-12, ventral view of fifth sterna; 13-16, ventral view of sixth sterna (see text for measurements). Protandrena bachue sp. nov. (2, 5, 7, 9, 13); P. guarnensis sp. nov. (12, 16); P. rangeli sp. nov. (4, 6, 11, 15); P. wayruronga sp. nov. $(3,8,10,14)$.

J. Ashe, R. Brooks, R. Hanley, ex: Rubus flowers. Paratypes: 5 ㅇ in total, three of them with the same data as the holotype, the other two with the following data: La Mucuy, Pedraza, Barinas. VII-4 1979, R. Brooks, R. Grigarick, J. McLaughlin, O. Schuster (SEMC).

Etymology. This species honors Prof. Maximina Monasterio at the Universidad de los Andes (Mérida, Venezuela), for all her efforts in promoting the study and conservation of high Andean ecosystems.

\section{Protandrena wayruronga $\mathbf{s p . ~ n o v . ~}$}

Diagnosis. This species is similar to $P$. bachue sp. nov. but differs by the shape of the clypeal yellow maculation (Fig. 3), shape of mandible (Fig. 8), number and distribution of midapical spines on S5 (Fig. 10), and pubescence on S6 (Fig. 14).

Holotype. Male. As described for $P$. bachue sp. nov. except for: Body length, about $8 \mathrm{~mm}$; head width $2.2 \mathrm{~mm}$ (apex of forewings damaged). Structure. Interalveolar distance 1.8 OD; ocellocular distance $3.1 \mathrm{OD}$, about $2 \mathrm{x}$ greater than ocelloccipital distance; interocellar distance $1.3 \mathrm{OD}$; compound eye about
$2 \mathrm{x}$ longer than wide; interantenal protuberance not as distinctly elevated as in $P$. bachue sp. nov.; facial fovea $2 \mathrm{x}$ longer than broad, about $0.4 \mathrm{x}$ scape length; scape $2.7 \mathrm{x}$ longer than broad; F1 1.5x longer than F2, 1.8x longer than F3. Stigma 4.2x longer than broad; prestigma nearly $3 \mathrm{x}$ longer than broad. Mesoscutum 5x longer than metanotum; S5-S8, and genital capsule as in Figs. 10, 14, 18, 22, 26, 30. Coloration. Clypeus with yellowish maculation as in Fig. 3. Punctation. Integument of clypeus and supraclypeal area shinier than in P. bachue sp. nov.

Holotype: $0^{x}$, ECUADOR, Napo: Papallacta [0 $20^{\circ}$ S, $78^{\circ} 8^{\prime} \mathrm{W}$, $3150 \mathrm{~m}]$, III-24 1983, Masner (SEMC).

Comments. We also examined a single female collected on XI-16 1970 from Puracé, a locality in Colombia [Departamento of Cauca, $2^{\circ} 15^{\prime} \mathrm{N}, 76^{\circ} 25^{\prime} \mathrm{W} ; 3400 \mathrm{~m}$ ] about $200 \mathrm{~km}$ north of Papallacta. The facial foveae and slightly modified antennae of this specimen are similar to the female of $P$. bachue sp. nov. but it is smaller, about the size of $P$. wayruronga sp. nov. This specimen, deposited in SEMC, might be the female of the latter species but we did not designate it as a paratype.

Etymology. The specific epithet means "bee" in the Quechua language. Quechua is the main spoken language by 

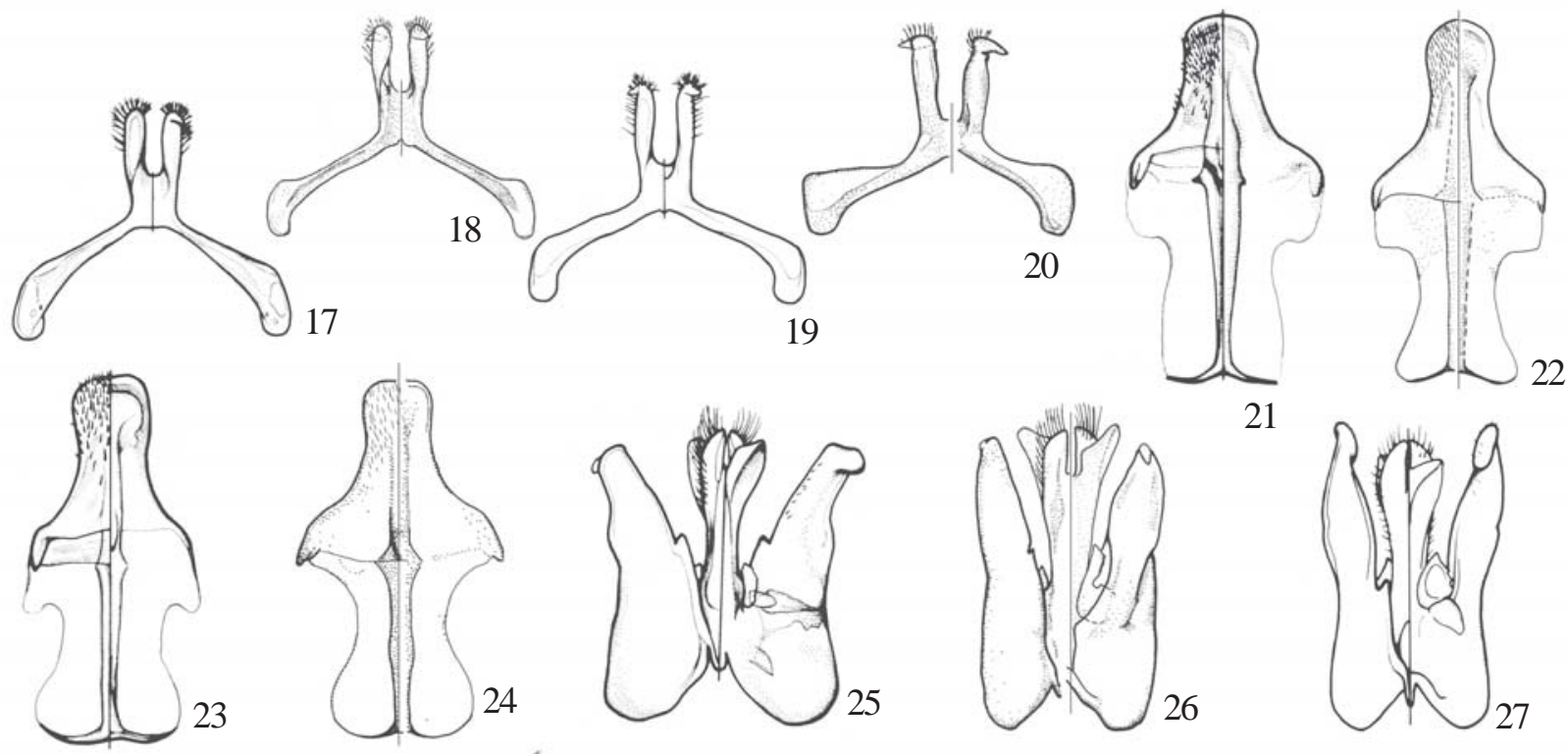

21
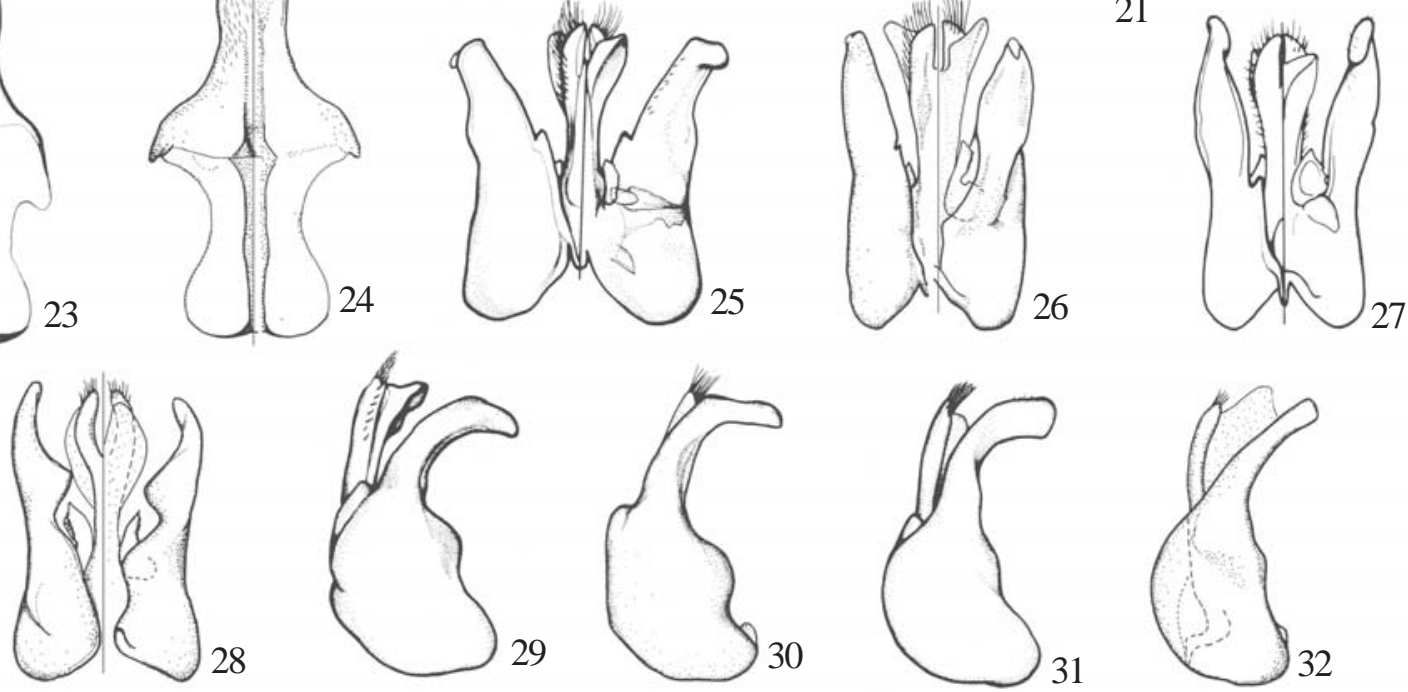

Figs. 17-32. Male genitalia and associated sterna of Protandrena. Dorsal (left half) and ventral (right half) views of seventh (17-20) and eighth (21-24) sterna, and genital capsule (25-28); 29-32, genitalia in lateral view (see text for measurements). Protandrena bachue sp. nov. (17, 21, 25, 29); P. guarnensis sp. nov. $(20,24,28,32)$; P. rangeli sp. nov. $(19,23,27,31)$; P. wayruronga sp. nov. $(18,22,26,30)$.

several indigenous populations of the Ecuadorian highlands, where this bee occurs.

\section{Protandrena rangeli sp. nov.}

Diagnosis. The male of this species can be distinguished by its small body size, unmodified antennal flagellum (Fig. 6), clypeus with a yellow maculation as in Fig. 4, and S5 with a row of four spines on the midapical margin (Fig. 11). The female of $P$. rangeli sp. nov. resembles that of $P$. maximina sp. nov. but it is smaller and has longer facial fovea than the latter (see also comparative comments on that species).

Holotype. Male. As described for $P$. bachue sp. nov., except for: Body length 5.7-6.1 mm; forewing length $4.3 \mathrm{~mm}$; head width $1.6-1.7 \mathrm{~mm}$. Structure. Head 1.2x wider than long; inner orbits convergent below (Fig. 4); interalveolar distance equal to the alveolorbital distance; alveolus diameter slightly smaller than OD; ocellocular distance $3 \mathrm{OD}, 1.9 \mathrm{x}$ greater than ocelloccipital distance; interocellar distance 1.2 OD; compound eye $1.7 x$ longer than wide, clypeus $2.2 x$ broader than long, projecting about half of eye width in lateral view; gena about two thirds of eye width in profile; frontal line elevated just above antennal sockets to three quarters of distance between antennal sockets and median ocellus, ending at that point; facial fovea 3.8x longer than broad; antennal flagellum unmodified (Fig. 6); F1 2.3x longer than F2 and 2.1x than F3. Stigma 3.9x longer than wide; prestigma $2.4 x$ longer than wide. Mesosoma narrower than maximum head width; mesoscutum $2.4 \mathrm{x}$ longer than mesoscutellum and $4.3 \mathrm{x}$ than metanotum; fore basitarsus similar in length and width to mid basitarsus; mid tibial spur straight, about half mid basitarsus length; S5-S8, and genital capsule as in Figs. 11, 15, 19, 23, 27, 31. Coloration. Antennal flagellum, tegula, legs, and metasoma dark reddish brown. Clypeus with a yellow maculation as in Fig. 4. Wings subhyaline, slightly brownish. Pubescence. Scape with hairs about $3 \mathrm{x}$ longer than its maximum diameter; fore and mid tibiae and tarsi of all legs, with pale yellow hairs. T1-T4 more densely covered with short (0.5 OD), semierect, pale ferruginous hairs than in P. bachue sp. nov. Punctation. Gena imbricate to coriaceous with faint punctures. Mesoscutum, mesoscutellum, and metanotum minutely punctured (1-2 PD), integument otherwise granular. Apical margin of terga weakly imbricate to smooth.

Female. As described for the male, except for usual secondary sexual characteristics: Body length 5.6-6.3 mm; forewing length $4.8-5.0 \mathrm{~mm}$; head width 1.6-1.8 mm. Structure. 


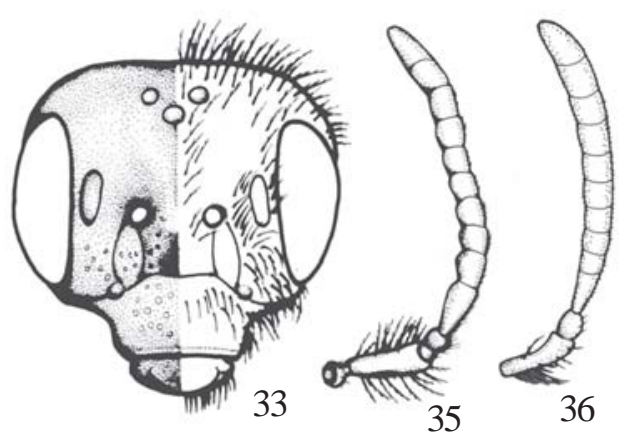

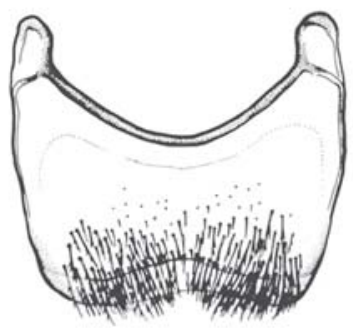

37
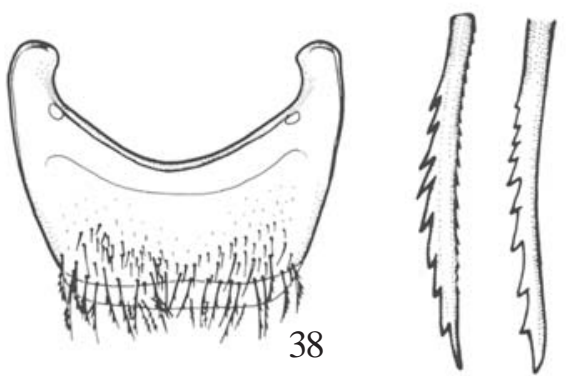

39
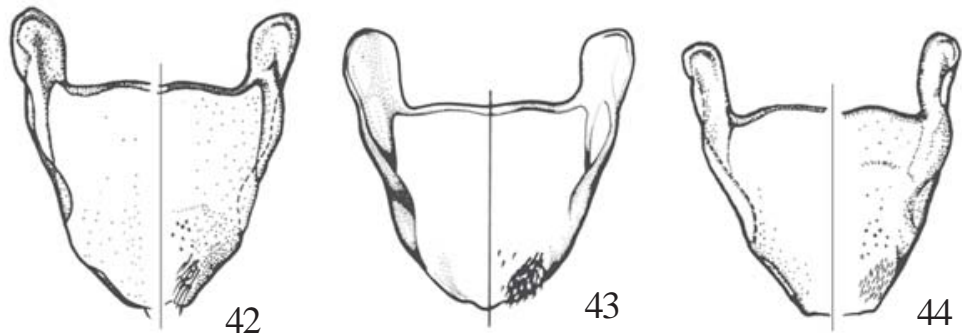

Figs. 33-44. Females of Protandrena. 33, 34, face showing integumental color (left half) and pubescence (right half), stippling indicates black; 35,36 , slightly crenulate and normal antennal flagella; 37, 38, ventral view of fifth sterna; 39, 40, mid tibial spur; 41-44, dorsal (left half) and ventral (right half) views of sixth sternum (see text for measurements). Protandrena bachue sp. nov. (33, 35, 37, 39, 41); P. guarnensis sp. nov. (44); P. rangeli sp. nov. (34, 36, 38, 40, 43); Protandrena wayruronga sp. nov. (42).

Inner orbits subparallel (Fig. 34); ocellocular distance 2.8 OD, $1.8 \mathrm{x}$ greater than ocelloccipital distance; interocellar distance 1.5 OD; compound eye $2.1 \mathrm{x}$ longer than wide, clypeus $2.3 \mathrm{x}$ broader than long; gena slightly narrower than eye in profile; facial fovea $4.3 x$ longer than broad, slightly shorter $(0.9)$ than scape length; antennal flagellum shorter than head width (Fig. 36 ); scape 2.8x longer than broad, F1 2.2x longer than F2 and F3 individually. Stigma 3.4x longer than wide. Mesosoma wider than head width; mesoscutum 2.6x longer than mesoscutellum, $4 \mathrm{x}$ longer than metanotum; mid tibial spur $0.7 \mathrm{x}$ mid basitarsus length, with nine coarse teeth (Fig. 40). Fovea of T2 $2 x$ longer than wide. S5 and S6 as in Figs. 38, 43. Pubescence. In general shorter and darker than in the male. Punctation. Metasomal sterna with denser (1-2 PD) punctures than in the male.

Holotype: $\sigma^{\star}$, COLOMBIA, Boyacá: Santuario de Fauna y Flora de Iguaque, Quebrada Carrizal, 2830 m, I-8 1992. C. Sarmiento (ICN). Paratypes: $30^{x}, 7$, one male and two females with the same data as the holotype; four females from the same locality but on the following dates and collectors: I-5 1992, VIII-21 1998, D. Forero; VII 2000, P. Reina; and two males from Cundinamarca, Bogotá, Universidad Nacional de Colombia, 2600 m, VIII-15 1999, V. Gonzalez (ICN, SEMC).

Etymology. This species honors Prof. Orlando Rangel (ICN) for his efforts in promoting the study and conservation of the floral diversity in Colombia. In addition, Prof. Rangel pioneered palynological research in the Andes.

Biological notes. One of us (VG) collected males of this species on Veronica persica Poir (Scrophulariaceae) and Oxalis sp. (Oxalidaceae) from gardens in the Universidad Nacional de Colombia, Bogotá. Also, on June 23 2000, VG found unemerged males and females inside their cells along a ditch next to the visitor center in Iguaque. The cells were approximately $4.1 \mathrm{~mm}$ in diameter and were located individually at the end of short (about $17 \mathrm{~mm}$ ) vertical tunnels that were filled with coarse soil. Individual nest entrances could not be found.

\section{Protandrena guarnensis sp. nov.}

Diagnosis. The species can be recognized by the combination of the following characters: antennal flagellum unmodified, long, in repose reaching the mesoscutellum in the male (Fig. 1); body dark reddish brown, without yellow marks in both sexes; face distinctly depressed, especially in the male, above alveolus toward ocellocular space. This depression resembles the antennal depression of Chilicola (Hylaeosoma) (Colletidae, Xeromelissinae). Other species closely related to P. guarnensis sp. nov. from Ecuador, Peru, and Bolivia have different combination of characters and their genitalia structure and associated sterna are quite different.

Holotype. Male. As described for P. bachue sp. nov. except for: Body length 4.6-5.2 $\mathrm{mm}$; forewing length 4.2-4.5 mm; head width $1.5-1.6 \mathrm{~mm}$. Structure. Inner orbits converging below; interalveolar distance subequal to alveolorbital distance, $2.5 \mathrm{x}$ greater than alveolar diameter, ocellocular distance 3.4 OD, $3.1 \mathrm{x}$ greater than ocelloccipital distance; interocellar distance $1.7 \mathrm{OD}$; compound eye $1.7 \mathrm{x}$ longer than wide; clypeus $2.6 \mathrm{x}$ broader than long, projecting $0.4 \mathrm{x}$ eye width in lateral view; gena $0.6 x$ eye width (Fig. 1); frontal line inconspicuous; facial 
fovea $2.5 x$ longer than broad; face distinctly depressed above alveolus toward ocellocular interval; scape 1.9x longer than broad, antennal flagellum unmodified, 1.2x longer than head width, reaching mesoscutellum in repose, F1 as long as broad, shorter than F2 and F3 individually, F2 slightly broader than long, remainder segments slightly longer than broad. Stigma $4.3 \mathrm{x}$ longer than wide; prestigma $3.3 \mathrm{x}$ longer than broad. Mesosoma about three fourths of head width; mesoscutum $3 \mathrm{x}$ longer than mesoscutellum and 4.7x than metanotum; fore basitarsus long and slender as mid basitarsus; mid tibial spur straight, $0.7 \mathrm{x}$ mid basitarsus length; hind tibial spurs straight, subequal in length; hind basitarsus with posterodistal margin strongly projected. Claws with rami of similar length. Metasoma distinctly petiolate; lateral fovea of T2 inconspicuous; S5-S8, and genital capsule as in Figs. 12, 16, 20, 24, 28, 32. Coloration. Predominantly dark reddish brown to black, without yellow maculations. The following parts light reddish brown: apex of mandible, legs, tegula, and metasoma. Pubescence. Mainly dark brown. Gena with grayish hairs as those on ventral area of mesepisternum. Mesoscutellum with hairs as long as those on disc of mesoscutum; tibia and tarsi of all legs, and metasoma with light ferruginous hairs. Metasoma more densely covered with short (0.5 OD) hairs than in P. bachue sp. nov.; T7 without median bare area. Punctation. Head with coarser punctures, especially on the clypeus, than in P. bachue sp. nov., integument between punctures mainly smooth and shiny. Mesoscutum, mesoscutellum, and metanotum with smaller, finer and sparser (1-2 PD) punctures than on head, integument shiny, distinctly imbricate between punctures.

Female. As described for the male, except for usual secondary sexual characteristics: Body length, $6 \mathrm{~mm}$; forewing length $5 \mathrm{~mm}$; head width $1.8 \mathrm{~mm}$. Structure. Head 1.4x wider than long; inner orbits slightly converging below; ocellocular distance $2.8 \mathrm{x}$ greater than ocelloccipital distance; interocellar distance $1.6 \mathrm{OD}$; compound eye $1.8 \mathrm{x}$ longer than wide; facial fovea 3.6x longer than broad, 0.7x scape length; antennal flagellum slightly shorter than head width, reaching posterior border of tegula; F1 longer than broad, 1.3x longer than F2 and F3 individually. Prestigma 4.3x longer than broad. Mesoscutum $3.5 x$ longer than mesoscutellum, $4.5 x$ longer than metanotum; fore basitarsus longer and slender than mid basitarsus; mid tibial spur with eight teeth; inner hind tibial spur slightly shorter than the outer. Claws with inner ramus distinctly shorter than the outer. Fovea of T2 weakly indicated by a darker spot, about $2 x$ longer than broad. S5 with apical margin straight, S6 as in Fig. 44.

Holotype: ơ, COLOMBIA, Antioquia: Guarne [6 $6^{\circ} 17 ' 55^{\prime \prime} \mathrm{N}$, 75²4'20'W], 2000 m, IX-3 1976, C. D. Michener (SEMC). Paratypes: $60^{x}, 1$ ㅇ with the same data as the holotype except for one male with the following data: Idem, $25 \mathrm{~km} \mathrm{~S}$ of Medellín, I-21 1984, J. H. Cane (SEMC).

Etymology. This specific epithet refers to the type locality of this species, Guarne, a beautiful rural area in the northwestern Andes of Colombia.

Acknowledgments. This paper is dedicated to Robert Brooks, who urged VG to describe and study these bees since 1999. We want to thank C. D. Michener for continuous advice and support. We also thank D. Bennet for providing the photographs and J. Pinzón for illustrations of $P$. bachue sp. nov. and $P$. rangeli sp. nov.; G. Bogotá and J. L. Fernández (ICN) for kindly identifying the pollen and plant samples; M. S. Engel and Z. Falin for access to bee specimens at SEMC, and L. Packer and C. Rasmussen for their comments and suggestions that helped improve this note. The University of Kansas (KU), Undergraduate Program in Biology, Department of Ecology and Evolutionary Biology, KU General Research Fund and US-Israel Binational Science Foundation grant 2000-259 (to D. Smith \& Y. Lubin) provided financial support for VG through teaching assistantships and laboratory facilities.

\section{REFERENCES}

Gonzalez, V. H. 2004. A new species of Acamptopoeum from Colombia (Hymenoptera: Andrenidae: Panurginae). Caldasia 26: 239-243.

Gonzalez, V. H. \& M. S. Engel. 2004. The Tropical Andean bee fauna (Insecta: Hymenoptera: Apoidea), with examples from Colombia. Entomologische Abhandlungen 62: 65-75.

Harris, R. A. 1979. A glossary of surface sculpturing. Occasional Papers in Entomology, California Department of Food and Agriculture 28: 1-31.

Michener, C. D. 2000. The Bees of the World. Johns Hopkins University Press. xiv+913 p.

Ramos, K. S. \& G. A. R. Melo. 2006. A new species of Protandrena Cockerell from Brazil (Hymenoptera, Apidae, Andreninae). Zootaxa 1330: 43-60.

Ruz, L. 1986. Classification and phylogenetic relationships of the panurgine bees. iii +312 p., Doctoral dissertation, University of Kansas, Lawrence, Kansas, USA.

Ruz, L. \& E. Chiappa. 2004. Protandrena evansi, a new panurgine bee from Chile (Hymenoptera: Andrenidae). Journal of the Kansas Entomological Society 77: 788-795. 